Fresh-Water Fishes" exhibited in the Department of Zoology of the British Museum (Natural History). This edition has been revised by the original author, Dr. C. Tate Regan; it is practically a reprint of the 1917 edition with one or two very minor alterations, but the paragraph on the common eel has been rewritten to include the new knowledge gained in recent years on the life-history of this fish through the researches of the late Dr. Johannes Schmidt. This publication, which is still priced at sixpence, is an invaluable little handbook for the identification of the fresh-water fishes of Great Britain.

\section{Amphibia and Reptiles of North China}

A concise and excellent "Handbook of North China Amphibia and Reptiles" by Dr. Alice M. Boring, C. C. Liu, and S. C. Chou, has been published as a Peking Natural History Bulletin (August 1932). It contains keys for the identification of the various families, and of eggs and tadpoles of the species of frogs and toads. The descriptions of the characteristic structures and habits of species, and the excellent drawings, should greatly help the natural history survey of the country, which is one of the objects of the Peking Natural History Society.

\section{Mr. T. Sheppard and the Naturalist}

WITH the close of $1932, \mathrm{Mr}$. T. Sheppard retired from the editorship of the Naturalist, having served it as editor for thirty years. As an illustrated monthly journal, designed for readers within the domain of the Yorkshire Naturalists' Union, the Naturalist has maintained a high standard, and in its comments and reviews it conveyed a touch of the editor's vitality and boisterousness. The occasion of his retirement was made an opportunity of presenting Mr. Sheppard with his portrait in oils by $\mathrm{Mr}$. Vincent Galloway.

\section{Kansu Earthquake of December 26}

EARLIER than was expected, reports have arrived from north-west China about the earthquake of December 26 (local time). From these, it appears that 280 persons were killed and 300 seriously injured, while 800 houses were destroyed. These losses occurred in the north-west of Kansu, one of the Chinese provinces most frequently visited by disastrous earthquakes.

\section{Announcements}

Dr. F. A. BAtHer has been awarded the Mary Clark Thompson medal of the National Academy of Sciences, Washington, "for his distinguished services in the fields of palæontology and geology".

THE tenth annual conference of the Association of Special Libraries and Information Bureaux will be held at the Wills Hall, Bristol, on September 22-24, under the presidency of Sir Charles Sherrington. Further particulars ean be obtained from the Secretary of the Association, 16, Russell Square, London, W.C.1.

AT the annual general meeting of the Association of Economic Biologists held in the Imperial College of Science, London, on February 24, the following officers for the ensuing year were elected:--Presi. dent, Prof. W. B. Brierley; Vice-Presidents, Prof. J. W. Munro, Prof. W. Brown; Hon. Treasurer, Diz. J. Henderson Smith; Hon. Editors, Prof. W. B. Brierley, Prof. J. W. Munro ; Hon. Secretaries, Prof. R. H. Stoughton, Mr. G. Fox-Wilson.

AT the ninety-first meeting of the American Association for the Advancement of Science, which was held on December 27-31, at Atlantic City, Prof. Henry Norris Russell, research professor in astronomy and director of the Observatory at Princeton University, was elected president for the ensuing year, and Prof. Henry B. Ward, who retires from the professorship of zoology in the University of Illinois in June next, was elected permanent secretary. The American Association prize of 1,000 dollars has been awarded to Dr. Henry Eyring, of Princeton University, for a paper entitled "Quantum Mechanies and Chemistry, with particular Reference to Reactions involving Conjugate Double Bonds".

The Oxford University Press will publish in April the first number of a new Empire Journal of Experimental Agriculture. This journal will offer agricultural research workers in the British Empire a medium for disseminating the records and results of their investigations on the feeding and management of livestock, cultivation and manuring of crops, trials of farm machinery, agricultural economics and experimental technique. The Journal will command a strong editorial Board, including, among others, Sir John Russell, Sir Rowland Biffen, Sir Daniel Hall, Sir Robert Greig, Sir Frederick Keeble and leading agricultural authorities in the chief countries of the Empire. Dr. E. H. Tripp, 40 Trewsbury Road, Sydenham, London, S.E.26, is secretary and general editor. The Journal will be published quarterly : subseription price 20s. for four numbers or single numbers $7 s$. $6 d$. net, each.

Applications are invited for the following appointments, on, or before, the dates mentioned:--A mathematics master at the Junior Technical School of the Wimbledon Technical College--The Principal (March 10). An assistant lecturer in zoology at the University of Manchester-The Registrar (March 11). A teacher in electrical engineering subjects at the Southall Technical College-H. M. Walton, Education Offices (H), 10, Great George Street, London, S.W.1 (March 21). A woman tutor in hygiene and biology at the Edge Hill Training College, Ormskirk, Liverpool-The Principal (March 24). A director of the Royal Technical College, Glasgow, and a professor of technical chemistry at the College-The Secretary (April 17). Physicists and electrical engineers for the staff of the Radio Research Board of the Commonwealth of Australia Council for Scientific ResearchF. L. McDougall, Australia House, Strand, W.C.2.

ERratum.-NATURE, February 25, p. 268, col. 2, paragraph entitled "Fat in Estivating Animals". line 13 for Pachyurus read Pachyuromys. 